\title{
63. THE SIZE DISTRIBUTION OF THE CENTRIC DIATOM COSCINODISCUS NODULIFER, SITE 480, GUAYMAS BASIN SLOPE, GULF OF CALIFORNIA ${ }^{1}$
}

\author{
David Murray and Hans Schrader, School of Oceanography, Oregon State University, Corvallis, Oregon
}

\begin{abstract}
Analysis of individual laminae in Recent sediments from the slopes of the Guaymas Basin indicates an increased abundance of the larger sizes ( $>60 \mu \mathrm{m}$ ) of Coscinodiscus nodulifer when upwelling conditions persist over the depositional site and an increase of the smaller sizes $(<60 \mu \mathrm{m})$ when nonupwelling conditions exist. The size distributions of C. nodulifer in 10-cm composite samples from Hole 480 show a greater abundance of the large sizes $(>60 \mu \mathrm{m})$ associated with well-laminated sections and more of the smaller sizes $(<60 \mu \mathrm{m})$ in samples from the homogeneous sections. We have tentatively correlated the pronounced homogeneous zones with late Pleistocene glacial periods. These results indicate a persistence of nonupwelling conditions over Hole 480 during glacial periods (homogeneous zones) and a predominance of upwelling conditions during interglacial periods (laminated zones). Other evidence from diatom and silicoflagellate floral analysis seems to support these preliminary conclusions.
\end{abstract}

\section{INTRODUCTION}

The recovery of a well-preserved, partly laminated diatomaceous section $(152 \mathrm{~m})$ from the east slope of the Guaymas Basin (Hole 480, Fig. 1) provides the basis for a detailed study of variations in late Pleistocene and Holocene floral assemblages. We believe these variations correspond to changes in the environment during this period. We further believe that a detailed study of the sediment provides a detailed account of the climatic and oceanographic variations responsible for the environmental changes. This chapter provides some preliminary results of a study on the size variation of a particular diatom species in samples from the length of the 152-meter section.

Numerous workers have studied size variations in specific diatom species found in the water column and sediments and have attempted to relate the distribution of cell diameters to environmental factors. Wimpenny (1936) relates increased amounts of large specimens of Rhizosolenia styliformis to an increase in temperature. Garstang (1937), looking at the same species, postulates that a mixing of populations from different water masses causes the size change. Margalef (1969) suggests a negative correlation between the size of Paralia sulcata and salinity. Burckle and Todd (1974) suggest that temperature and nutrient supply may change the size of $A n$ nellus californicus. Numerous studies (Kolbe, 1954; Belayeva, 1972; Burckle and McLaughlin, 1977; Maloney and Burckle, 1979) proposed that increased nutrient supply to the surface waters (upwelling) or water-mass fluctuations affect the size distribution of $C$. nodulifer.

We examined the size distribution of $C$. nodulifer (a polyhaline, subtropical-tropical oceanic species) at various levels in Hole 480. We also analyzed near-surface sediment samples. Short cores from both sides of the Guaymas Basin provided recent analog samples to assist

\footnotetext{
${ }^{1}$ Curray, J. R., Moore, D. G., et al., Init. Repts. DSDP, 64: Washington (U.S. Govt. Printing Office).
}

in interpreting the results obtained from the studies of older sediment in Hole 480.

\section{METHODS}

We took scrapings from the working half of material from Hole 480 at $10-\mathrm{cm}$ intervals along the entire length of the core. Using methods outlined by Schrader and Gersonde (1978), we then prepared selected samples from laminated and homogenous sections (Table 1) for diatom analysis. Our preparation differed in that we boiled the samples in $\mathrm{H}_{2} \mathrm{O}_{2}$ and sodium pyrophosphate to remove organic matter and disperse the clay-sized material. This method also preserved the $\mathrm{CaCO}_{3}$ skeletal material. We wet sieved the samples through a $150-\mu \mathrm{m}$ mesh to separate the coarse fraction (see Crawford and Schrader, this volume) from the remaining material. Permanent mounts were prepared from the $<150-\mu \mathrm{m}$ portion for diatom analysis using methods described by Schrader and Gersonde (1978).

We observed that $C$. nodulifer was absent in the coarse fraction $(>150 \mu \mathrm{m})$.

During a cruise to the central Gulf of California in September of 1979 , our group at Oregon State University recovered more recently deposited laminated sediment material (Fig. 1, Areas A, B, C, D, and E). We sampled individual laminae using toothpicks; srmear slides were made using Aroclor 4465 as a mounting medium. One of the cores taken on the Baja side (Fig. 1, Area C) contained a homogeneous section overlying a laminated section, an alternation similar to that found on a larger scale in material from Hole 480 (Schrader, Kelts, et al., 1980a). We took composite surface scrapings from this core and prepared them for diatom analysis in the same manner as the material from Hole 480 .

The slides were examined for $C$. nodulifer specimens. We measured the diameters with an eyepiece reticle calibrated with a stage micrometer. We measured the diameters of $C$. nodulifer specimens and put them in $10-\mu \mathrm{m}$ classes $(0-9,10-19,20-29$, and so forth). Approximately 100 individuals were measured in each sample.

\section{OBSERVATIONS}

Figures 2 through 5 are histogram plots of the percentage of individuals counted in each size class. The size distribution of samples from individual laminae (Fig. 2) shows an increase in specimens with sizes $>60$ $\mu \mathrm{m}$ in laminae showing characteristics of upwelling assemblages (Schrader, Murray, et al., 1980b). To produce the type of size distribution expected from a composite sample within a laminated section (Fig. 3), we combined the $C$. nodulifer measurements from individ- 


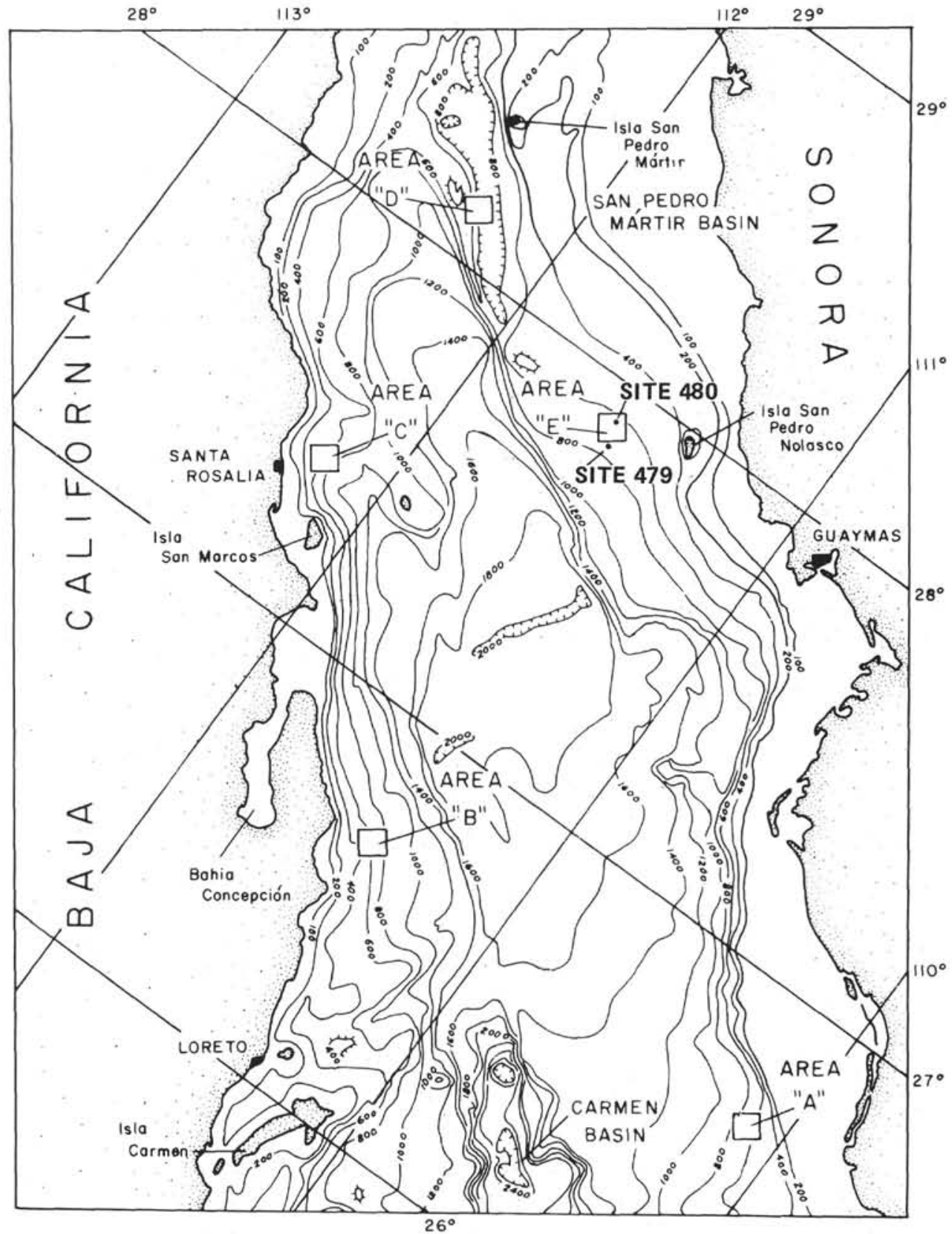

Figure 1. Areas A, B, C, D, and E (Cruise BAV79) and Leg 64 Sites 479 and 480 (depth contours in meters).

ual adjacent laminae containing upwelling and nonupwelling assemblages. Note that there is still a predominance of individuals $>60 \mu \mathrm{m}$. Figure 4 illustrates the results of composite samples from recent homogeneous and laminated sections in Area C. The samples show an increasing abundance of smaller-size classes within the homogeneous samples. The $19.5-27 \mathrm{~cm}$ sample from a homogeneous zone (Area $\mathrm{C}$ ) does not exhibit a strong shift in the mode to smaller sizes. (More will be said on this type of distribution later in the chapter.)

Results of the analysis of samples taken at selected intervals from Hole 480 are shown in Figure 5. Except for Sample 480-2-3, 70-80 cm, we found abundant $C$. nodulifer ( $>100$ per slide) in samples from Cores 1 through 14. Coscinodiscus nodulifer occurs in minor amounts in samples down to the base of Core 17. Representative samples from Cores 18 through 26 suggest an absence of C. nodulifer in this interval. Coscinodiscus nodulifer reappears in minor amounts in Core 27 , is highly abundant in Core 29, and absent in Core 31.

The modes decrease in value from Core 1 (laminated) to Core 4 (nonlaminated) and then increase to Core 6 (laminated) (Fig. 5). Another clear transition seems to occur in Core 11 (laminated), decreases to Core 13 (nonlaminated), and then increases to Core 14 (laminated). These sections seem to fit the general model of a greater abundance of individuals $>60 \mu \mathrm{m}$ in the laminated sections, with a greater abundance of individuals $<60 \mu \mathrm{m}$ in the nonlaminated sections. Samples from Cores 8 through 10 do not show this distinct difference. But 
Table 1. Composite surface scraping samples from Hole 480 .

\begin{tabular}{|c|c|c|}
\hline Sample & Source & Distribution \\
\hline $1-1,0-10$ & $\mathrm{~L}$ & $P$ \\
\hline $1-1,10-20$ & $\mathrm{~L}$ & $\mathrm{P}$ \\
\hline $2-3,70-80$ & $\mathrm{~L}$ & NP \\
\hline $3-3,20-30$ & NL & $\mathrm{P}$ \\
\hline $4-3,30-40$ & NL & $\mathrm{P}$ \\
\hline $5-2,120-130$ & NL & P \\
\hline $6-2,90-100$ & $\mathrm{~L}$ & $P$ \\
\hline $6-3,20-30$ & NL & P \\
\hline $8-2,20-30$ & NL & $\mathbf{P}$ \\
\hline $8-2,100-110$ & L & $\mathrm{P}$ \\
\hline $9-3,20-30$ & NL & $\mathrm{P}$ \\
\hline $10-1,130-140$ & L & P \\
\hline $11-1,100-110$ & L & $\mathrm{P}$ \\
\hline $11-1,140-150$ & $\mathrm{~L}$ & $\mathrm{P}$ \\
\hline $13-1,0-10$ & NL & $\mathrm{P}$ \\
\hline $14-1,90-100$ & L & $\mathrm{P}$ \\
\hline $15-2,10-13$ & NL & RP \\
\hline $16-2,120-130$ & $\mathrm{~L}$ & RP \\
\hline $17-1,100-110$ & NL & TP \\
\hline $17-3,40-50$ & $\mathrm{~L}$ & TP \\
\hline $18-1,0-10$ & NL & NP \\
\hline $18-3,80-90$ & $\mathrm{~L}$ & NP \\
\hline $19-2,0-10$ & NL & NP \\
\hline $20-2,120-130$ & $\mathrm{~L}$ & NP \\
\hline $22-1,0-10$ & NL & NP \\
\hline $22-3,50-60$ & L & NP \\
\hline $25-1,20-30$ & $\bar{L}$ & NP \\
\hline $26-1,110-120$ & $\mathrm{~L}$ & NP \\
\hline $27-1,70-80$ & NL & TP \\
\hline $27-3,10-20$ & L & NP \\
\hline $29-2,30-40$ & L & $\mathbf{P}$ \\
\hline $31-1,30-40$ & $\mathrm{~L}$ & NP \\
\hline
\end{tabular}

Note: $\mathrm{L}=$ well laminated, $\mathrm{NL}=$ not laminated (homogeneous), $\mathrm{P}=C$. nodulifer present $(>100$ on the slide), NP $=C$. nodulifer not present (barren), $\mathrm{TP}=C$. nodulifer trace $(<10$ on the slide), $\mathrm{RP}=C$. nodulifer rare (10-100 on the slide).

samples from the homogeneous sections of these latter cores are from mottled sediment containing disturbed laminae. Thus the sediment could have first been laminated and should show a laminated or mixed laminatedhomogeneous size distribution, as in the samples from Cores 8 and 9.

\section{DISCUSSION}

Roden (1964) describes atmospheric and oceanographic conditions in the Gulf of California. From November to May, when northwesterly winds persist, coastal upwelling of nutrient-rich waters occurs on the mainland side of the Guaymas Basin. It occurs on the Baja side from July to September when southwesterly winds persist. The main terrigenous contribution occurs on both sides of the basin from runoff during the summer months. These conditions cause the annual deposition of a light and dark laminae couplet. Our analysis of individual laminae shows a greater abundance of terrigenous and opaque organic material associated with the darker layers. A hypothesis for laminae formation on both sides of the Guaymas Basin (Schrader, Murray, et al., 1980b) proposes that upwelling occurs during the formation of the light layer on the mainland side (north-

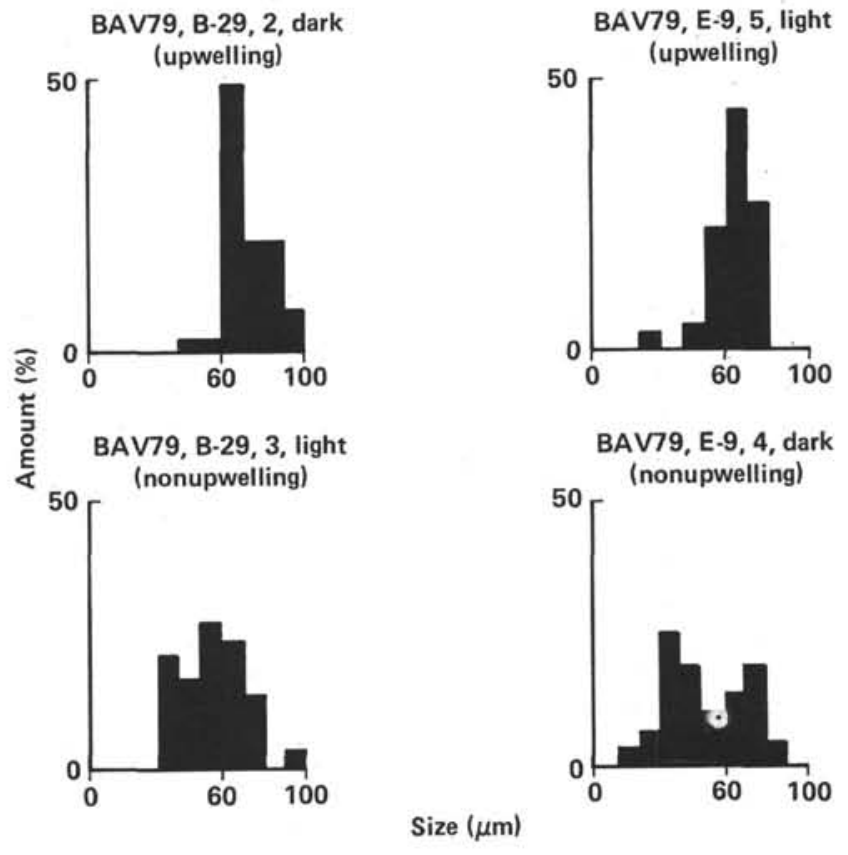

Figure 2. Size distribution of Coscinodiscus nodulifer in adjacent individual laminae from Cores BAV79, E-9 (mainland side of Guaymas Basin) and BAV79, B-29 (Baja side of Guaymas Basin). (The samples were taken from core depths of 110 and $48 \mathrm{~cm}$, respectively.)

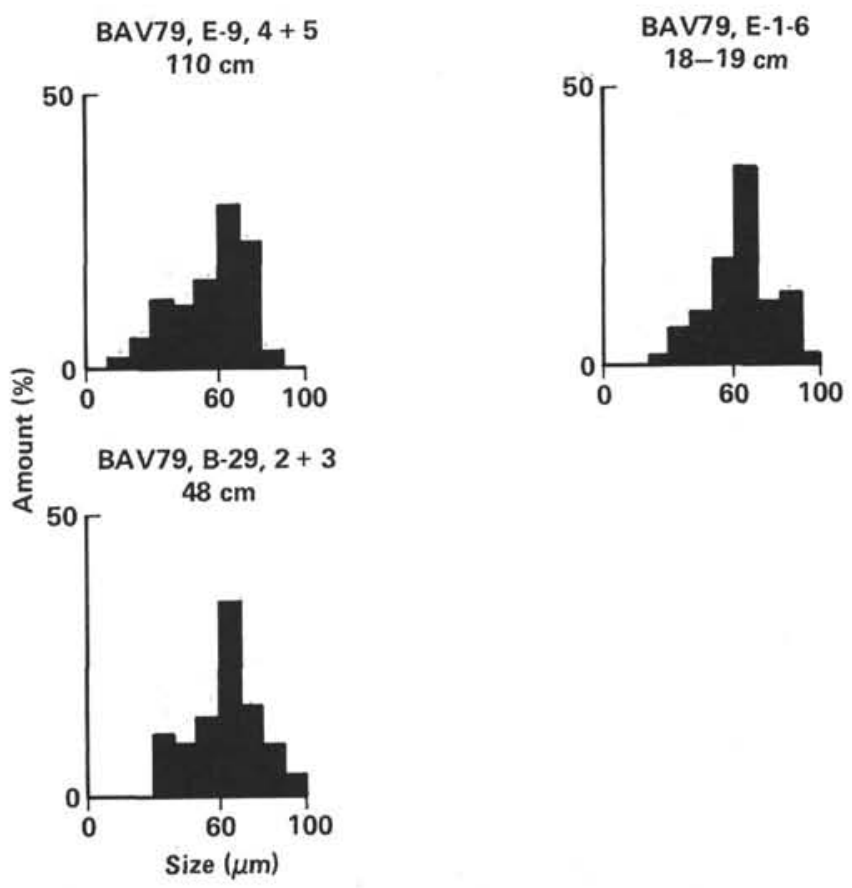

Figure 3. Size distribution of $C$. nodulifer based on the combination of counts from individual adjacent laminae in Cores BAV79, E-9 and BAV79, B-29. (Counts of the individual laminae in the first two distributions are shown in Fig. 2. E-1-6 is a combination of counts from six adjacent laminae in Core E-9 at a depth of 18-19 cm.)

westerly winds and no terrigenous contribution) and the dark layer on the Baja side (southeasterly winds and terrigenous contribution). Results of the lamina by lamina study of samples from Recent material (Fig. 2) indicate 


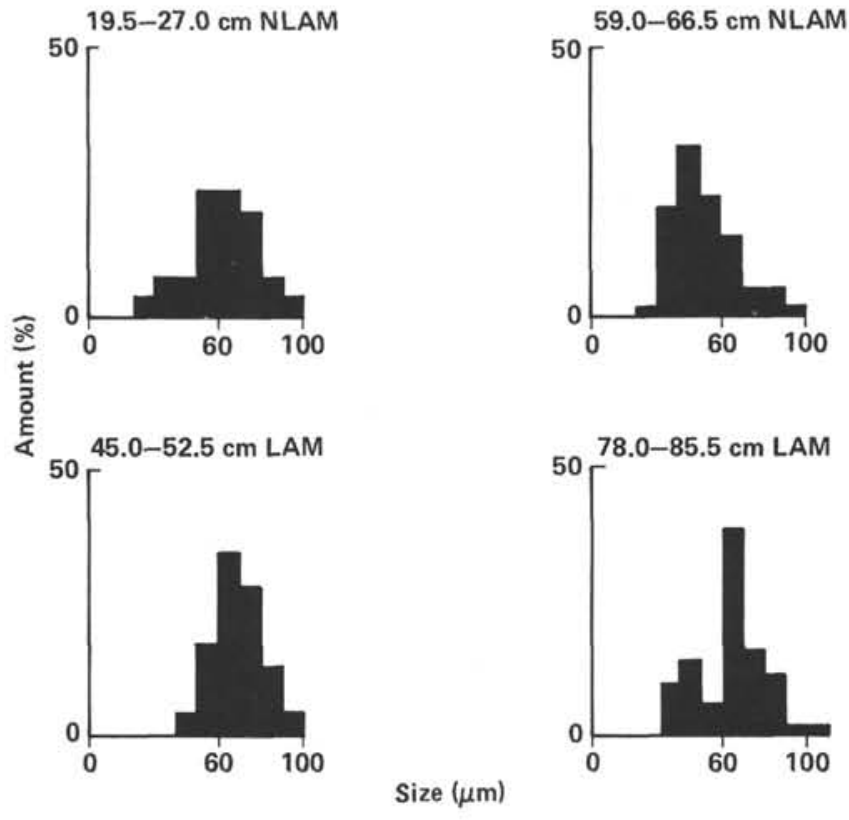

Figure 4. Size distribution of $C$. nodulifer from $7.5-\mathrm{cm}$ composite samples of homogeneous and laminated sections in Core BAV79, C-25. LAM $=$ laminated section; NLAM $=$ homogeneous section.

that during upwelling, there is a greater abundance of $>60-\mu \mathrm{m}$-cell-diameter Coscinodiscus nodulifer. Larger individuals are associated with lighter laminae on the mainland side (Areas A and E and Hole 480) and with darker laminae on the Baja side (Areas B and C).

The size distribution for the combined laminae samples (Fig. 3) reflects a mixing of upwelling and nonupwelling end members. In most of the layers, however, there is a greater abundance of Coscinodiscus nodulifer specimens in the "upwelling laminae." Thus these upwelling layers generally contribute greater numbers of C. nodulifer to the total and increase the contribution of specimens of the larger-sized classes. The time span of a $10-\mathrm{cm}$ composite sample from a laminated section would be approximately 100 years, and samples from a homogeneous section would represent a slightly longer period (Crawford and Schrader, this volume, Pt. 2). When upwelling did not persist over the time interval represented by the composite sample, the distribution toward the smaller-sized individuals was skewed; when upwelling persisted, greater numbers of the larger sizes were observed. This can then be related to the distributions seen in Figures 4 and 5.

Cores from the slopes of the Guaymas Basin exhibit fine laminations if the sediments were deposited where the oxygen-minimum zone impinges on the basin slope (Calvert, 1966). We believe the homogeneous sections represent periods when the oxygen-minimum zone shifted away from the area of deposition, thus permitting the support of a benthic population capable of bioturbating the sediments. The absence of, or a decrease in, upwelling of nutrient-rich waters could lead to lower primary productivity in the surface waters and thus to a decreased flux of organic carbon to the seafloor. Less oxygen would be needed for the decomposition of this organic material, and oxygen would be available to support a rich benthic life.

The top $35 \mathrm{~cm}$ of sediment in Area C (Fig. 1) is homogeneous and contains brittle stars and small burrowing mollusks on the surface of the section. The homogeneous zone overlays a laminated section, indicating a change in the relatively recent past, from anoxic to oxic conditions - conditions that support a rich benthic population. Nevertheless, the size distribution of $C$. nodulifer in a composite sample from this homogeneous zone (Area C, 19.5-27 cm) shows approximately equal amounts of sizes $<60 \mu \mathrm{m}$ and sizes $>60 \mu \mathrm{m}$. This may indicate that part of the material was deposited during upwelling and was postdepositionally mixed, by burrowing organisms, with sediment characteristic of nonupwelling conditions. Thus only some of the homogeneous sections or part of these sections may represent continuous nonupwelling conditions.

A mixing of two end member distributions (upwelling and nonupwelling) also accounts for the size distribution of results from composite samples taken along the 152-meter section from Hole 480. This would show a decrease in the predominant upwelling conditions from the top surface (laminated) to Core 4 (homogeneous) and then an increase to the top of Core 6 (laminated). Core 4 is the first major homogeneous zone, and we tentatively correlated it with the last major glaciation (Schrader et al., in press). During that time, there was a eustatic lowering of sea level that would have affected the Gulf of California. This lowering would shift the upwelling zones and the oxygen-minimum zone farther offshore and would permit benthic life to become established in Hole 480. The predominance of the smaller (nonupwelling-associated) individuals in the homogeneous zone supports this hypothesis. A similar sequence occurs in Cores 10 through 14 (Core 12 was not recovered; a sand lens[?]) with the top of Core 13 representing a period of low sea-level stand and an absence of upwelling over the site.

Initial data from silicoflagellate counts in these samples indicate a greater abundance of Dictyocha epiodon and Distephanus speculum, associated with the cooler California Current (Poelchau, 1974), in the distinctly homogeneous zones already mentioned. These species reach high abundance in samples from Cores 4 and 9. Between 0 and 71 meters (Cores 1-14) in Hole 480 , combined Coscinodiscus nodulifer and silicoflagellate data indicate three major periods of cold water influx or nonupwelling.

Silicoflagellate species data also indicate the general absence of $C$. nodulifer in Cores 17 through 27. Samples from the base of Core 18 to Core 27 show a high abundance of Dictyocha epiodon and Distephanus speculum and a predominance of $D$. speculum over other silicoflagellates in samples from Cores 20 through 22 . This indicates that temperatures in the area were perhaps too cold to support a population of $C$. nodulifer, a diatom generally associated with warm waters (Kolbe, 1957). 

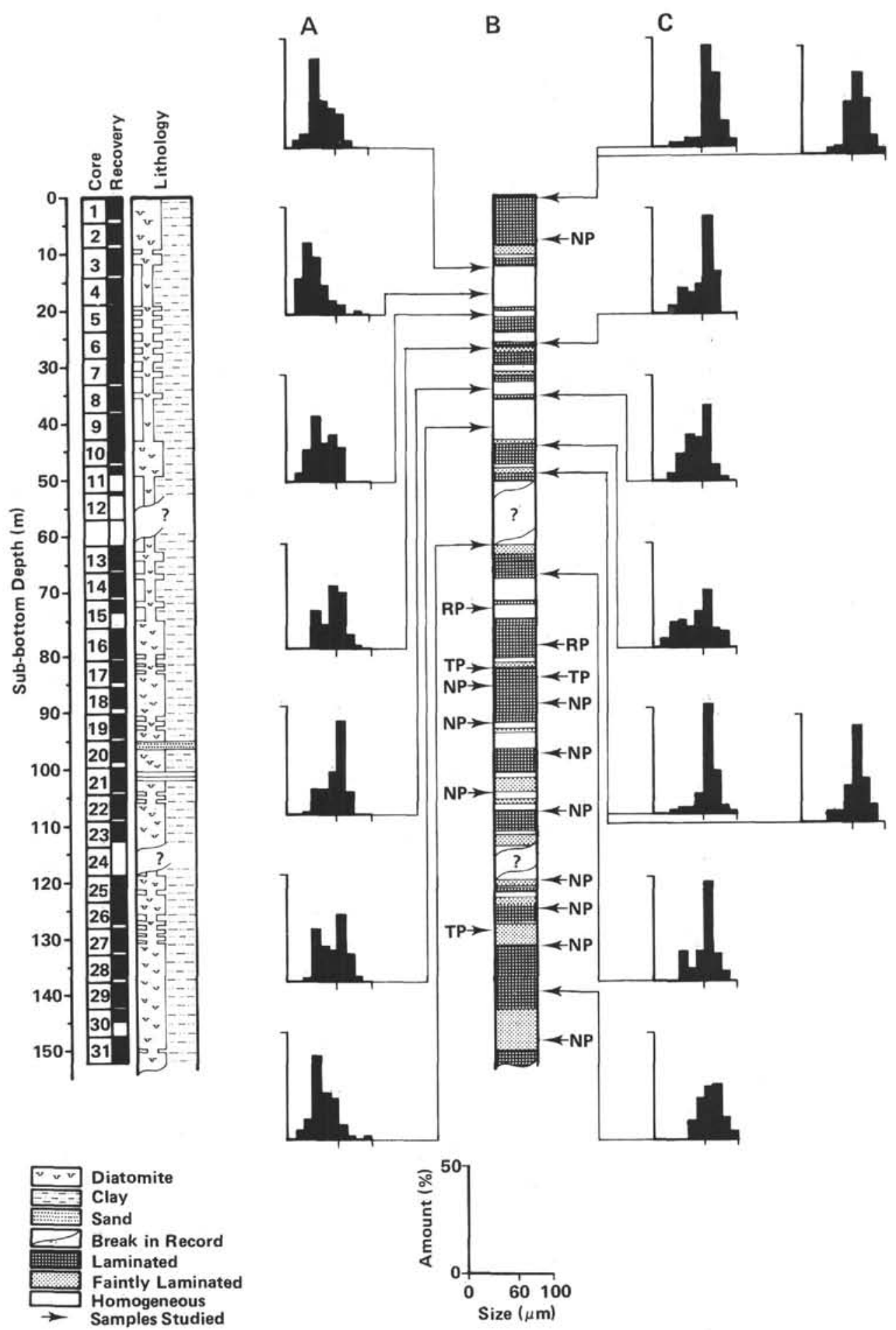

Figure 5. Site log of Hole 480. (A. Size frequency distributions of $C$. nodulifer in samples from nonlaminated sections; arrows indicate sample source [NP, TP, RP definitions in Table 1] B. Simplified textural interpretation. C. Size frequency distributions of $C$. nodulifer in samples from laminated sections. [See Table 1 for exact locations of samples.] Black intervals in Recovery Records indicate recovered material; white intervals indicate unrecovered material).

There would then be a lag, beginning at the base of Core 18 , between this cold period and the development of a sizeable population, allowing the preservation of $C$. nodulifer in the sediment record (Core 16).

Another possibility for the lack of $C$. nodulifer during particular times might be that other species were abundant for a time and excluded $C$. nodulifer from the area. We have noticed that Coscinodiscus asteromphalus fragments are abundant in many samples where C. nodulifer is low in abundance or lacking entirely. A hypothesis of species competition may account for the absence of $C$. nodulifer in Sample 480-2-3, 70-80 cm or 
the brief flood of $C$. nodulifer in samples from Core 29 . Analyzing more samples from these sections and counting the species will help to resolve these questions.

Comparing the results from this study with other studies of the size variation of $C$. nodulifer indicates that the size of this species is highly variable. Data from the equatorial Pacific (Arrhenius, 1952; Burckle and McLaughlin, 1977; Maloney and Burckle, 1979) and the equatorial Atlantic (Schrader and Schuette, in press) show bimodal distributions of valve diameters. These are thought to represent a mixing of two distinct populations, with each population or size class favored by particular environmental conditions. The total size range of $C$. nodulifer in the equatorial Atlantic is much smaller $(10-60 \mu \mathrm{m})$ than that for the equatorial Pacific $(10-200 \mu \mathrm{m})$. The range for specimens in the Gulf of California is from 10 to $110 \mu \mathrm{m}$.

One explanation for the bimodal distributions may be that two different populations are thriving in the area: one population with diameters of 10 to $70 \mu \mathrm{m}$ and one with diameters of 50 to $110 \mu \mathrm{m}$. The larger sizes may be favored during nutrient-rich conditions, as suggested by our analysis and studies in the equatorial Pacific (Burckle and McLaughlin, 1977).

Another explanation may be that the two size classes represent a single population. It is known that vegetative cell division occurs with decreasing cell size until a particular size range is reached. Environmental factors (Drebes, 1977) then induce sexual reproduction, which restores the initial, larger cell size. It may be that, during favorable conditions, the cell size at which environmental factors are effective in ending vegetative reproductive division is larger, and thus a population of larger individuals is maintained. Based on data from other studies, along with our own, we tend to support the multiple population hypothesis.

\section{CONCLUSIONS}

This preliminary study does not give any conclusive evidence about the causes of variation in the size distribution of Coscinodiscus nodulifer in Hole 480. We do suggest that there is an association between a predominance of larger individuals $(>60 \mu \mathrm{m})$ and welllaminated sections and a correlation between the smaller individuals $(<60 \mu \mathrm{m})$ and well-established homogeneous sections. These associations are controlled by environmental events, such as upwelling and temperature variations.

Because of the excellent recovery of core material from Hole 480, the study of the size distribution of $C$. nodulifer can become very detailed. The next step will be to fill in some of the important gaps in the data and to try to "fine tune" this technique to detect the ecological changes that have occurred in this area from the late Pleistocene to the Present.

\section{ACKNOWLEDGMENTS}

We thank Steve Crawford for his work in obtaining and preparing the samples used in this study. Gail Davis typed the various drafts of this chapter. Gretchen Schuette, John Barron, and Lloyd Burckle reviewed the manuscript. The research was supported by NSF grants OCE77-20624 and ATM79-19458.

\section{REFERENCES}

Arrhenius, G., 1952. Sediment cores from the east Pacific. In Petterssen, H. (Ed.), Reports of the Swedish Deep-Sea Expedition 19471948 (Vol. 5): Göteborg (Elanders).

Belayeva, T., 1972. Distribution of large diatom algae in the southeastern Pacific. Okeanologiya, 12:475-483.

Burckle, L. H., and McLaughlin, R. B., 1977. Size changes in the marine diatom Coscinodiscus nodulifer A. Schmidt in the equatorial Pacific. Micropaleontology, 23:216-222.

Burckle, L. H., and Todd, A., 1974. Size differences in the diatom Annellus californicus Tempere. Paleontol. Soc. Jpn. Trans. (n.s.), 437-441.

Calvert, S. E., 1966. Origin of diatom-rich, varved sediments from the Gulf of California. J. Geol., 76:546-565.

Drebes, G., 1977. Sexuality. In Werner, D. (Ed.), The Biology of Diatoms. Botanical Monographs, 13: Oxford (Blackwell), 250-283.

Garstang, W., 1937. On the size changes of diatoms and their oceanographic significance. J. Mar. Biol. Assoc. U.K., 22:83-96.

Kolbe, R. W., 1954. Diatoms from equatorial Pacific cores. In Petterssen, H. (Ed.), Reports of the Swedish Deep-Sea Expedition 1947-1948 (Vol. 5): Göteborg (Elanders).

1957. Diatoms from equatorial Indian Ocean cores. In Petterssen, H. (Ed.), Reports of the Swedish Deep-Sea Expedition 1947-1948 (Vol. 6): Göteborg (Elanders).

Maloney, J. I., and Burkle, L. H., 1979. Size change in C. nodulifer in Pleistocene sediments of the equatorial Pacific-stratigraphic and paleo-oceanographic implications. Trans. Am. Geophys. Union, 60:273. (Abstract)

Margalef, R., 1969. Size of centric diatoms as an ecological indicator. Mitt. Int. Ver. Limnol., 17:202-210.

Poelchau, H., 1974. Holocene silicoflagellates of the North Pacific [Ph.D. dissert.]. University of California, San Diego.

Roden, G. I., 1964. Oceanographic aspects of the Gulf of California. In van Andel, Tj. H., and Shor, G. G. (Eds.), Marine Geology of the Gulf of California: A Symposium. Am. Assoc. Pet. Geol. Mem. 3:30-58.

Schrader, H., Curray, J., and Moore, D., et al., in press. Laminated diatomaceous sediments from the Guaymas Basin Slope (Central Gulf of California): An over 250,000 year climate record by hydraulic-piston-core. Proc. Gulf California Sym., Mazatlan, 1979.

Schrader, H. J., and Gersonde, R., 1978. Diatoms and silicoflagellates. Utrecht Micropaleontological Bulletin, 17:129-176.

Schrader, H., Kelts, K., Curray, J., et al., 1980. Laminated diatomaceous sediments from the Guaymas Basin Slope (Central Gulf of California): 250,000 year climate record. Science, 207:1207-1209.

Schrader, H., Murray, D., Matherne, A., et al., 1980. Laminated marine sediments in the central Gulf of California. Geol. Soc. Am. Cordilleran Section. Abstract with programs, 12:151-152. (Abstract)

Schrader, H. J., and Schuette, G., in press. Marine diatoms. The Sea (Vol. 7): New York (John Wiley).

Wimpenny, R. S., 1936. The size of diatoms, 1. The diameter variation of Rhizolenia styliformis Brighton, and $R$. alata Brighton, in particular and of pelagic marine diatoms in general. J. Mar. Biol. Assoc. U.K., 21:29-60. 